\title{
Cattle-deer interactions in the Sierra Nevada: A bioeco- nomic approach
}

\author{
JOHN B. LOOMIS, ERIC R. LOFT, DOUGLAS R. UPDIKE, AND JOHN G. KIE
}

\section{Abstract}

Four potential cattle grazing systems on summer range in the Sierra Nevada are compared in terms of deer harvest, number of hunters attracted, and the net economic value of hunting. Research on deer carrying capacity response to different 3-year rest rotation grazing patterns indicates continuous moderate grazing provides 82\% of the potential deer carrying capacity. A 2-years-off, 1-yearon grazing system provides $94 \%$ of potential deer carrying capacity. The increase in carrying capacity associated with grazing 1 year in 3 could increase buck harvest by 200 animals in the Slerra Nevada's hunt zone D5. Change in deer harvest in the previous year is one of the key variables in a model that determines the attactiveness of hunt zones to California deer hunters. The model predicts that increasing buck harvest by 200 deer in hunt zone D5 results in 2,721 more hunters visiting this zone each year. This translates into nearly 11,835 more trips. The net economic value of these additional hunters is determined based on a simulated market approach. Using the value from the hunter survey, the annual increase in hunting value is $\mathbf{5 2 . 3}$ million. The present value of this change over each 3-year rest-rotation cycle is $\mathbf{5 6 . 5}$ million using a $4 \%$ discount rate. The incremental benefits of deer hunting gained under the 2-years-off, 1-year-on grazing system is greater than the lost net economic value of the forage to the rancher as computed by USDA Economic Research Service.

Key Words: cattle systems, home range, mule deer, deer hunting benefits, non-market valuation, net economic benefits, $O$ docoileus hemionus

While cattle can have positive effects on wildlife through their effects on vegetation composition and structure, their effects are generally considered to be negative because of the disruption to 'natural'systems. For example, there is evidence that cattle grazing can have negative effects on mule deer (Odocoileus hemionus) (Menke 1977, Peek and Dalke 1982, Loft et al. 1987). Whether the net effects of cattle grazing are significant depends on management objectives, stocking rate, timing of grazing, and wildlife species of concern (Kie and Loft 1990). One objective of this paper is to report on recent research regarding the effect of alternative cattle grazing systems on mule deer home ranges on Sierra Nevada summer range.

To minimize the adverse effects of livestock grazing on deer often requires curtailing some facet of current livestock use, whether it be a reduction in stocking rate, shortening the season of use, or implementation of a rest-rotation system. These actions understandably meet with resistance from livestock operators. However, on public lands the intent of multiple use legislation is to optimize the sum of all of the multiple use values, not maximize one resource value at the expense of substantially reducing

\footnotetext{
Authors are associate professor, Division of Environmental Studies and Department of Agricultural Economics, University of California, Davis 95616; wildlife biologists, California Department of Fish and Game, 1416 Ninth Street, Sacramento, 95814; and research wildlife biologist, Pacific Southwest Forest and Range Experiment Station, U.S. Forest Service, 2081 E. Sierra Ave., Fresno, Calif. 93710.

The authors wish to thank Dr. Peter Hunter, University of California, Davis, who performed the programming for this model. His willingness to accommodate our many requests for making the model user friendly is greatly appreciated. Statistical analysis on the deer hunter prediction model was performed by Michael Creel, Department of Agricultural Economics, University of California, Davis. Of course only the authors bear responsibility for what follows in this paper.

Manuscript accepted 25 October 1990.
}

another. While livestock have always had a directly observable economic value, the economic value of wildlife has not been as obvious. Crawford (1986) points out that without commensurate values of wildlife and recreation, public land management agencies such as the Bureau of Land Management have a difficult time justifying what they believe, but cannot demonstrate, is more balanced multiple use.

In this study we present a microcomputer economic model that quantifies the economic value of deer hunting in California by statistically estimating dollar values that are directly comparable to livestock values. This model makes calculating these conceptually comparable deer hunting values easier for range conservationists, wildlife biologists, and land managers in California as well as serving as a prototype model for other states. The model enables wildlife-livestock trade-off analyses similar to what was originally carried out by Martin et al. (1978), but without requiring new surveys or statistical analysis in California. The second objective of this paper is to use this microcomputer economic model to evaluate 4 alternative cattle grazing systems on deer summer range in the Sierra Nevada of California. Implications of the results to range management on national forests are then discussed.

\section{Study Area}

\section{Mule Deer on Sierra Nevada Summer Range}

During spring, mule deer migrate from low elevation winter ranges to mountain summer ranges in the Sierra Nevada. Female mule deer give birth on the summer range and remain until autumn storms signal the return to winter range. Summer is a nutritionally demanding time for lactating deer (Klein 1965, Moen 1973) and they rely on high quality forage and cover to nourish and hide young fawns. As part of their summer home range in the Sierra Nevada, female mule deer prefer mountain meadow, riparian, and aspen (Populus tremuloides) habitats because of the high quality herbaceous forage and cover present (Loft 1988). Reproductive success of deer and consequent production of "huntable" deer is dependent upon the capacity of their range to provide food and cover (Julander et al. 1961, Pederson and Harper 1978).

\section{Methods}

Most of the summer range is administered as national forest land by the U.S. Forest Service, hence livestock, primarily cattle, are also present on the range. Cattle prefer the same habitats as female mule deer and in this regard compete with them for resources in preferred habitats (Loft et al. 1991). Research was conducted by Loft (1988) and Loft et al. (1991) on mule deer response to 3 levels of cattle grazing: no grazing, moderate grazing (.71 AUM/ha), and heavy grazing (1.33 AUM/ha) over a 3-year period in the Stanislaus National Forest. Deer activity (resting, feeding, and travelling) was measured using radio collared deer with activity 'tip' switches.

This research demonstrates that moderate grazing, (approximating the grazing level of the previous 10-20 years) decreased the availa bility of hiding cover for deer in meadow-riparian and aspen habitats (Loft et al. 1987), reduced use of preferred habitats by deer (Loft et al. 1991), increased home range size of deer (Loft 1988), and increased the time deer spent feeding compared to no grazing 
(J.G. Kie personal communication). Heavy grazing had similar effects, but to a greater amount. For example, deer home range sizes as estimated by the adaptive kernel method (Worton 1989) averaged 88 ha during no grazing, 103 ha during moderate grazing, and 124 ha during heavy grazing. These values represented increases in home range area of $18 \%$ and $41 \%$ during moderate and heavy grazing, respectively, compared to no grazing.

The high energetic requirements of lactation and the quality of the range forage play an important role in influencing the home range size of female mule deer. Home range size is often inversely related to food supply (Schoener 1981, Ford 1983) and is unlikely to be larger than the minimum size necessary to provide key resources (Mace et al. 1983). Cattle grazing reduced cover and herbaceous forage available to deer in mutually preferred meadowriparian and aspen habitats (Loft et al. 1987). These reductions were responsible in part for the increased time spent feeding by deer (J.G. Kie personal communication) and the increases in home range size.

Female deer are aggressive and territorial during the time fawns are young, and often chase other deer away from areas where their fawns are hiding (Geist 1981). The increased size of deer home ranges with cattle grazing would increase the frequency of these aggressive encounters. Furthermore, the loss of hiding cover for fawns and the increased time spent feeding by adult deer both suggest increased vulnerability to predation (Mangel and Clark 1986, Loft et al. 1987).

These empirical results and conclusions, combined with general theory that predicts an inverse relationship between home range size and carrying capacity (McNab 1963, Schoener 1981), lead us to argue that cattle grazing on summer range in the Sierra Nevada decreases carrying capacity for mule deer. For purposes of input to the economic model presented here, it is assumed that the increase in deer home range size under moderate (18\% increase) and heavy ( $41 \%$ increase) grazing compared to no grazing, directly translate to proportional reductions in deer carrying capacity on summer range. These recent studies also suggest that in this area of the Sierra Nevada, it is summer, not winter range that is more limiting. In part, this is due to fire suppression efforts adversely affecting vegetation composition and structure, data indicating that fawn survival on the summer range is low and that deer summering in the area migrate to 4 distinct winter ranges. Thus, changes in summer range carrying capacity is the critical factor although given the dynamic feature of habitats, such changes likely vary in the long-term.

\section{Methods Used in Bio-economic Model}

The bio-economic model is made up of 2 components: (1) a submodel that predicts the change in the number of hunters that will hunt in a particular zone based on changes in characteristics of a hunting site and (2) a net economic value of hunting submodel.

The model's geographic scope is the state of California. The database used to develop the model was obtained from a 1987 survey of California deer hunters. The mail questionnaire was jointly designed by California Department of Fish and Game, University of California-Davis, and several state and federal land management agencies. The sample was a systematic sample of $5 \%$ of all hunters visiting each hunt zone. The data used to estimate the model parameters reflects responses from 8,788 completed questionnaires with an overall response rate of $60 \%$. A copy of the entire survey instrument can be found in Loomis et al. 1989.

The hunter-use prediction submodel was estimated using a multinomial logit equation. This prediction model estimates the probability a hunter will select a particular hunt zone as a function of the 4 independent variables: season length, hunter success rate in that hunt zone, total hunt zone harvest (both for the previous year as this is the latest information available to the hunter when he determines which zone to hunt in), and travel cost (roundtrip distance times hunters reported cost per mile). All of these variables were statistically significant at the $5 \%$ level or higher (see Loomis et a. 1989 for more details). A change in the value of any of these variables in a hunt zone will result in a new estimate of the number of hunters going to a zone. The change in number of hunters translates into a change in number of trips, using data on the average number of trips a hunter takes to a zone during the season. Once the number of trips is calculated, the net economic value of these trips to the hunters must be determined using the contingent valuation economic submodel.

The contingent valuation method (CVM) is a market simulation approach used by Federal agencies for valuing recreation and nonmarketed natural resources (U.S. Water Resources Council 1979, 1983; U.S. Department of Interior 1986). CVM measures the hunter's net willingness to pay over and above their current trip cost. The method has shown to be reliable (Loomis 1989) and provides reasonably valid measures of actual cash willingness to pay for deer hunting (Welsh 1986). This measure of the economic efficiency benefits of hunting is conceptually comparable to that of livestock forage values derived from ranch budgets-optimization techniques (which measure change in net income to the rancher) or fair market value surveys of what AUMs lease for.

In this application, a dichotomous choice format was used in which hunters were asked if they would have made their last hunting trip to their particular hunt zone if the cost per trip had been $\$ X$ higher. The $\$ X$ varied from $\$ 2.50$ to $\$ 700$. The yes/no responses to this question were used to estimate a logistic regression. The coefficients from the logistic regression allows calculation of expected willingness to pay for the sample. In essence, the probability of stating "yes would pay" is computed at each dollar amount and the expected value of willingness to pay is calculated (see Loomis 1988 or Hanemann 1984). Performing such calculations on the logistic regression for the hunt zone used in this study (D5) yields a value of \$194 per trip. This means a typical hunter's maximum bid to be able to take deer hunting trips in this hunt zone is an additional $\$ 194$.

\section{Evaluation of Alternatives Cattle Grazing Systems}

Allotments in the Sierra Nevada are usually grazed continuously each summer between June and late September. Alternatives to continuous summer-long grazing are rest-rotation grazing systems in which a pasture or allotment would be rested for 1 or more years (Stoddart et al. 1975). Rest-rotation grazing is particularly appropriate in temperate latitudes and on mountain rangelands where cool-season grasses comprise most of the vegetation (Hormay 1956, Johnson 1965, Ratliff et al. 1972). It should be noted that periodic grazing can have desirable effects on the vegetation community. For example, cattle can be used to help maintain seral vegetation which is desirable to deer.

The specific grazing and hunting study site is located southeast of Sacramento and extends to the crest of the Sierra Nevada. The area, known as hunt zone D5, lies largely within the Eldorado National Forest. Research results of Loft et al. (1987) and Loft (1988) on the adjacent (within $3 \mathrm{~km}$ ) Stanislaus National Forest apply equally well to the Eldorado because of similarities in elevations, orientation, vegetation communities, habitat, livestock grazing patterns, and the deer herd.

To accommodate both deer and cattle objectives, 3 different rest-rotation grazing systems were analyzed and compared to the current continuous moderate grazing system. The grazing systems could be implemented on the scale of 3 grazing allotments, or within 1 allotment divided into thirds (designated as pastures A, B, and $C$ ). No cost of additional fencing (if needed) to implement a rest-rotation grazing scheme was considered in the analysis. The first grazing system considered was to implement 2 years of non- 
Table 1. Rest-rotation grazing systems used in economic analysis of mule deer versus cattle in the Sierra Nevada. $\mathbf{M}=$ moderate grazing, $N U=$ non-use, $\mathbf{H}=$ heavy grazing. Letters $\mathbf{A}, \mathbf{B}$, and $\mathbf{C}$ represent either 3 pastures or 3 allotments and illustrate over 3 year cycle (year 4 begins the cycle again), the year(s) that use or non-use by cattle would occur.

\begin{tabular}{|c|c|c|c|c|}
\hline \multirow[b]{2}{*}{ Grazing system } & \multicolumn{4}{|c|}{ Year } \\
\hline & 1 & 2 & 3 & 4 \\
\hline $\begin{array}{l}\text { (M,M,M) } \\
\text { Use } \\
\text { Non-use }\end{array}$ & $\begin{array}{c}\mathbf{A}, \mathbf{B}, \mathbf{C}, \\
-\end{array}$ & $\begin{array}{c}\mathrm{A}, \mathrm{B}, \mathrm{C} \\
-\end{array}$ & $\begin{array}{c}\mathbf{A}, \mathbf{B}, \mathbf{C}, \\
-\end{array}$ & $\begin{array}{c}\mathbf{A}, \mathbf{B}, \mathbf{C}, \\
-\end{array}$ \\
\hline $\begin{array}{l}\text { (NU,M,M, and } \mathrm{NU}, \mathrm{H}, \mathrm{H} \text { ) } \\
\text { Use } \\
\text { Non-use }\end{array}$ & $\underset{\mathrm{C}}{\mathrm{A}, \mathrm{B}}$ & $\begin{array}{c}\mathrm{A}, \mathrm{C} \\
\mathbf{B}\end{array}$ & $\begin{array}{c}\mathrm{B}, \mathrm{C} \\
\mathrm{A}\end{array}$ & $\begin{array}{c}\mathbf{A}, \mathbf{B} \\
\mathbf{C}\end{array}$ \\
\hline $\begin{array}{l}\text { (NU,NU,M) } \\
\text { Use } \\
\text { Non-use }\end{array}$ & $\begin{array}{c}\mathrm{C} \\
\mathrm{A}, \mathrm{B}\end{array}$ & $\begin{array}{c}\mathbf{B} \\
\mathrm{A}, \mathrm{C} \\
\end{array}$ & $\begin{array}{c}\mathbf{A} \\
\mathbf{B}, \mathbf{C}\end{array}$ & $\begin{array}{c}\mathrm{C} \\
\mathrm{A}, \mathrm{B}\end{array}$ \\
\hline
\end{tabular}

use by cattle, followed by 1 year of moderate grazing (Table 1 ). Assuming that a permittee was grazing cattle every summer, this grazing system would decrease the allowable AUM's by two-thirds compared to current grazing. The second grazing system would implement 1 year of non-use followed by 2 years of moderate grazing, and would reduce current AUMs by one-third. The third grazing system was developed to minimize impact on the permittee by maintaining the current number of AUMs by implementing 1 year of non-use followed by 2 years of heavy grazing.

\section{Methods for Determining Livestock Grazing Values Foregone}

There is an opportunity cost of foregone livestock grazing for the alternatives combining non-use and moderate grazing. To calculate the amount of forage not available to cattle during non-use we used data on AUM production by vegetation type in hunt zone DS from the Eldorado National Forest Plan (USDA Forest Service 1989). Vegetation types providing livestock forage included grassland, meadow, perennial forbs, sagebrush, and broadleaf trees. Three-fourths of the total AUMs came from the grassland and meadow vegetation types. Slightly less than 3,000 AUMs of forage would be consumed under moderate grazing in hunt zone D5 each year. Over the 3-year grazing cycle this would total 9,000 AUMs. Under the first rest-rotation system involving 2 years of non-use, this would drop to 3,000 AUMs. With only 1 season of non-use the 9,000 AUMs would be reduced to 6,000 AUMs.

To calculate the net economic value of the AUMs foregone, we used the \$12.82 per AUM value of forage from the Eldorado Forest Plan. This value is developed for the U.S. Forest Service by USDA Economic Research Service using ranch budget data and a linear programming model of rancher adjustments to changes in AUMs (Gee 1981). The $\$ 12.82$ per AUM represents the maximum net willingness to pay by the rancher for the forage over and above the current federal grazing fee of $\$ 1.35$ per AUM in 1987. Such a value is conceptually comparable to the net willingness to pay values of hunting calculated in this study using the contingent valuation method.

\section{Results}

\section{Translation of Grazing Changes to Deer Carrying Capacities}

Using the results from the deer biology studies cited above we estimated continuous grazing increases home range size and reduces deer carrying capacity by $18 \%$ compared to no grazing. Therefore, continuous moderate grazing provides only $82 \%$ of the potential carrying capacity available under no grazing. The rest-rotation system involving 2 years of non-use (NU, NU, M), results in an average of $94 \%$ of the potential carrying capacity above the 3-year period for an increase of $14.6 \%$ over the current grazing system
$(M, M, M)$. The rest-rotation system involving 1 year of non-use (NU,M,M), results in an average of $88 \%$ of the potential carrying capacity for an increase of $7.3 \%$ above the current system. The 2 years of heavy use, 1 year of non-use grazing system $(\mathrm{H}, \mathrm{H}, \mathrm{NU})$ results in a reduction of deer carrying capacity to $73 \%$ of the no grazing potential.

Based on the theoretical expectation that an animal's home range is no larger than the minimum area needed to obtain essential resources, once the changes in carrying capacity, as reflected in home range sizes, have occurred and deer herd's populations have adjusted, one would expect the long-term average population to rise by about the same amount as the increase in carrying capacity. Current harvest of deer in hunt zone D5 is assumed to reflect the current carrying capacity associated with continuous moderate grazing. The percentage change in carrying capacity achieved by implementing the rest-rotation grazing systems is applied to current harvest to compute new long run harvests under the new systems.

The bio-economic model uses 1986 harvests as the base, since the hunter survey data is from 1987 and we have evidence from the site-selection model statistical analysis that hunters base their hunting decisions on the previous season harvest statistics. The base deer harvest for D5 was 1,374 in 1986 and is associated with the current continuous moderate grazing pressure. Therefore, predicted 3-year average harvest levels associated with each restrotation grazing system would be 1,575 for the first system (NU,NU,M), 1,475 for the second system (NU,M,M) and 1,217 for the third system $(\mathrm{H}, \mathrm{H}, \mathrm{NU})$.

Inputting these new expected harvest levels for hunt zone DS into the bio-economic management model will change the level of the harvest variable in D5 in the multinomial logit model of hunter site selection. This will result in a new predicted number of hunters expected to visit D5. The additional hunters will generate additional trips which will be valued at the $\$ 194$ net willingness to pay per trip value for deer hunting in zone D5 (derived as described above). The annual values are then converted to a present value over the 3-year cycle. The resulting benefit estimates for the different grazing systems are presented in Table 2.

The present value of the forage (at the $\$ 12.82$ per AUM described earlier) is calculated using the same $4 \%$ discount rate over the 3-year grazing cycle. The present value loss of AUMs under the first system's 2 years of non-use, followed by 1 year of moderate grazing, is $\$ 71,153$. The second system, which involves only 1 year of non-use followed by 2 years of moderate grazing, has a present value loss of $\$ 35,577$.

\section{Comparison of Benefits and Costs}

Comparing the benefits (Table 2) gained from the different rest-rotation grazing systems to the losses in livestock forage values demonstrates the gain to society from implementing these restrotation grazing systems. The greatest gain (more than $\$ 6$ million) occurs with the first rest-rotation system that involves 2 years of non-use and 1 year of moderate grazing (NU,NU,M). Even 1 year of non-use could increase social benefits by over $\$ 3$ million. Thus, while the original continuous grazing system may have made sense in previous decades of high beef demand and low deer hunting values, economic efficiency can be improved today by reallocating forage from lower value cattle production to higher value deer hunting opportunity through rest-rotation grazing systems. Additionally, such systems add a dimension of diversity to the natural communities in that they would be grazed periodically rather than annually at the same level. Periodic disturbance by cattle could be used to help maintain a diverse system and the seral vegetation deer rely on. 
Table 2. Current and expected deer harvest levels for each grazing system $(\mathrm{NU}=$ non-use, $\mathrm{M}=$ moderate livestock grazing, $\mathrm{H}=$ heavy livestock grazing; Present value calculated over 3 year grazing cycle using a $4 \%$ discount rate, Dif = difference from $\mathbf{M}, \mathbf{M}, \mathbf{M}$ ).

\begin{tabular}{|c|c|c|c|c|c|c|c|c|}
\hline $\begin{array}{l}\text { Grazing } \\
\text { System }\end{array}$ & $\begin{array}{c}\text { Increase } \\
\text { in deer } \\
\text { over } \\
\mathbf{M}, \mathbf{M}, \mathbf{M}\end{array}$ & $\begin{array}{c}\text { Deer }^{1} \\
\text { harvest }\end{array}$ & $\begin{array}{l}\text { No. of }{ }^{2} \\
\text { hunters }\end{array}$ & $\begin{array}{l}\text { No. of } \\
\text { trips }\end{array}$ & $\begin{array}{l}\text { Annual } \\
\text { economic } \\
\text { value }\end{array}$ & $\begin{array}{c}\text { Difference } \\
\text { (Millions of Dollars) }\end{array}$ & $\begin{array}{l}\text { Present } \\
\text { Value }\end{array}$ & $\begin{array}{l}\text { Differ- } \\
\text { ence }\end{array}$ \\
\hline$\overline{\mathrm{M}, \mathrm{M}, \mathrm{M}}$ & - & 1374 & 22456 & 97684 & $\$ 18.95$ & -- & $\$ 52.59$ & - \\
\hline NU, NU, M & $14.6 \%$ & 1575 & 25177 & 109520 & $\$ 21.25$ & $\$ 2.30$ & $\$ 59.06$ & $\$ 6.5$ \\
\hline $\mathrm{NU}, \mathrm{M}, \mathrm{M}$ & $7.3 \%$ & 1475 & 23793 & 103500 & $\$ 20.08$ & $\$ 1.3$ & $\$ 55.72$ & $\$ 3.1$ \\
\hline NU,H,H & $-12.0 \%$ & 1217 & 20494 & 89149 & $\$ 17.32$ & -1.63 & $\$ 48.06$ & -4.5 \\
\hline
\end{tabular}

'Input to economic model

2Output of economic model

${ }^{3}$ Number of hunters times 4.35 trips per season per hunter

${ }^{4}$ Number of trips times $\$ 194$ net willingness to pay per trip from model

\section{Discussion and Conclusion}

This paper demonstrated the application of the California deer bioeconomic management model to valuing increases in deer hunting predicted to occur with greater deer carrying capacity. Increased carrying capacity was achieved in this case study implementing a rest-rotation grazing system involving 1 or more years of non-use on a 3-year cycle. The gain in net economic value of hunting greatly exceeded the loss to society from reduced livestock production necessary to bring about the increase in deer hunting value. Thus, the model can be quite useful to public land management agencies in developing more optimal multiple-use management strategies for livestock and deer on public lands.

The California deer bioeconomic management model can be applied to quantify the net economic value and income/employment effects of changes in harvest of deer for a variety of other causal factors as well. As demonstrated here, the model has the potential to link the ecology of deer management to economic values. In addition, changes in deer hunting quality such as success rate, increasing opportunities to harvest a trophy deer or bagging an additional deer that are a result of habitat improvement projects can also be quantified into dollar terms using the California deer management model. The model is flexible enough that it can be applied to analyze changes in harvest or success rate that arise from habitat impacts, habitat improvement projects or changes in hunting regulations, due to changing deer populations.

This model may serve as a useful tool for land managers to develop hunt zone specific economic information about different impacts (both positive and negative) to deer hunting in California.

\section{Literature Cited}

Crawford, J. 1986. Land use planning in the Bureau of Land Management. Trans. North American Wildlife and Natural Resources Conf., Wildlife Management Institute 51st. (Washington DC) 51:403-410.

Ford, R.G. 1983. Home range in a patchy environment: optimal foraging predictions. Amer. Zool. 23:315-326.

Gee, K. 1981. Estimating economic impacts of adjustments in grazing on federal lands and estimating federal rangeland forage values. Colorado State Univ. Exp. Sta., Tech. Bull. 143. Fort Collins.

Geist, V. 1981. Behavior: Adaptive strategies in mule deer. pp. 157-223 In: Mule and black-tailed deer of North America (ed. O.C. Wallmo). Univ. Nebraska Press, Lincoln.

Hanemann, M. 1984. Welfare evaluations of contingent valuation experiments with discrete responses. Amer. J. Agr. Econ. 66:332-341.

Julander, O., W.L. Robinette, and D.A. Jones. 1961. Relation of summer range condition to mule deer herd productivity. J. Wildl. Manage. 25:54-60.

Hormay, A.L. 1956. How livestock grazing habits and growth requirements of range plants determine sound grazing management. J. Range Manage. 9:161-164.
Johnson, W.M. 1965. Rotation, rest-rotation, and season-long grazing on a mountain range in Wyoming. USDA Forest Serv., Rocky Mt. Forest and Range Exp. Sta. Res. Pap. RM-14. Fort Collins, Colo.

Kie, J.D., and E.R. Loft. 1990. Wildlife Habitat in California Annual Grasslands and Mountain Meadows Communities. Proc. 43rd Soc. Range Manage. Meeting, Reno, Nev.

Klein, D. 1965. Ecology of deer range in Alaska. Ecol. Monogr. 35:259-284.

Loft, E.R., J.W. Menke, J.G. Kie, and R.C. Bertram. 1987. Influence of cattle stocking rate on the structural profile of deer hiding cover. J. Wildl. Manage. 51:655-664.

Loft, E.R. 1988. Habitat and spatial relationships between mule deer and cattle in a Sierra Nevada forest zone. Ph.D. Thesis. Univ. of California, Davis.

Loft, E.R., J.W. Menke, and J.G. Kie. 1991. Habitat shifts by mule deer: the influence of cattle grazing. J. Wildl. Manage. 55:(in press).

Loomis, J. 1988. Contingent valuation method using dichotomous choice Models. J. Leisure Res. 20:46-56.

Loomis, J. 1989. Test-retest reliability of the contingent valuation method. Amer. J. Agr. Econ. 71:76-84.

Loomis, J., M. Creel, and J. Cooper. 1989. The economic benefits of deer in California: Hunting and viewing values. Inst. Ecol. Rep. 32. Univ. of California, Davis.

Mace, G., P. Harvey, and T.H. Clutton-Brock. 1983. Vertebrate homerange size and energetic requirements. pp. 32-53. In: Swingland, I.R. and P.J. Greenwood, Eds. The ecology of animal movement. Clarendon Press, Oxford.

Mangel, M., and C. Clark. 1986. Towards a unified foraging theory Ecology 67:1127-1138.

Martin, W., J. Tinney, and R. Gum. 1978. A welfare economic analysis of the potential competition between hunting and cattle ranching. West. J. Agr. Econ. 3:87-97.

McNab, B.K. 1963. Bioenergetics and the determination of home range size. Amer. Nat. 97:133-140.

Menke, J.W.,(ed). 1977. Proc. workshop on livestock and wildlife-fisheries relationships in the Great Basin. Pub. 3301, Univ. California, Berkeley.

Moen, A. 1973. Widlife ecology: An analytical approach. W.H. Freeman, Co., San Francisco, Calif.

Orians, G.H., and N.E. Pearson. 1979. On the theory of central place foraging. pp 155-177 In: D.J. Horn, R.D. Mitchell, and G.R. Stairs. eds. Analysis of ecological systems. Ohio State Univ. Press, Columbus.

Pederson, J.C., and K.T. Harper. 1978. Factors influencing productivity of two mule deer herds in Utah. J. Range Manage. 31:105-110.

Peek, J.M., and P.D. Dalke. (eds), 1982. Wildlife-livestock relationships symposium: Proc. 10. Univ. Idaho, Moscow.

Pennycuick, C.J. 1979. Energy costs of locomotion and the concept of 'foraging radius'. pp 164-184 In: A.R.E. Sinclair and M. NortonGriffiths, eds. Serengeti: dynamics of an ecosystem. Univ. Chicago Press, Chicago, Ill.

Ratliff, R.D., J.N. Reppert, and R.J. McConnen. 1972. Rest-rotation at Harvey Valley: Range health, cattle gains, and costs. USDA Forest Serv., Pacific Southwest Forest and Range Exp. Sta. Res. Pap. PSW-77. Berkeley, Calif.

Schoener, T.W. 1981. An empirically based estimate of home range. Theor Pop. Biol. 20:281-285.

Stoddart, L.A., A.D. Smith, and T.W. Box. 1975. Range management, 3rd edition. McGraw-Hill Book Co., New York. 
U.S. Department of Agriculture, Forest Service. 1989. Eldorado National Forest Plan, Final Environmental Impact Statement. Placerville, Calif. U.S. Department of Interior. 1986. Natural Resource Damage Assessments; Final Rule. Federal Register 43 CFR Part 11; Vol 51(148):2767427753.

U.S. Water Resources Council. 1979. Procedures for evaluation of National Economic Development (NED) benefits and costs in water resources planning (Level C). Federal Register, 44(243):72892-72976.

U.S. Water Resources Council. 1983. Economic and environmental principles for water and related land resources implementation studies. Gov. Printing Office.
Waser, P.M., and R.H. Wiley. 1979. Mechanisms and evolution of spacing in animals, pp. 159-223 In: P. Marler and J. Vandenbergh, eds. Handbook of behavioral neurobiology: (3). Social behavior and communication. Plenum Press, N.Y.

Welsh, Michael. 1986. Exploring the accuracy of the contingent valuation method: Comparisons with simulated markets. Unpubl. Ph.D. Diss. Dep. of Agr. Econ., Univ. Wisconsin, Madison.

Worton, B.J. 1989. Kernel methods for estimating the utilization distribution in home-range studies. Ecology 70:164-168. 